\title{
The Relevance of Project-Based Lecture in Industrial Revolution 4.0: Meta - Synthesis Study
}

\author{
Tristan Rokhmawan ${ }^{1} \&$ Badriyah Wulandari \\ Sekolah Tinggi Keguruan dan Ilmu Pendidikan PGRI Pasuruan, Indonesia
}

Corresponding Author: Tristan Rokhmawan,

(2) Tristanrokhmawan19890821@gmail.com

\begin{tabular}{|c|c|}
\hline \multirow{3}{*}{$\begin{array}{l}\text { ARTICLE INFO } \\
\text { Article history: } \\
\text { Received } \\
7 \text { August } 2019 \\
\text { Revised } \\
\text { 11 November } 2019 \\
\text { Accepted } \\
\text { 23 December } 2019\end{array}$} & ABSTRACT \\
\hline & $\begin{array}{l}\text { The researchers conducted a meta-synthesis study of the concept of } \\
\text { project-based lectures and the concepts of the development of the IR } 4.0 \\
\text { era. The main goal of this study was to examine a rational relationship or } \\
\text { relevance between the application of project-based lectures and the } \\
\text { development of the educational paradigm in the Industiral Revolution } \\
\text { (IR) } 4.0 \text { era. The result showed that the seventh project-based lecture } \\
\text { features can realize the educational context in the IR } 4.0 \text { era. The result } \\
\text { Meta-Synthesis in two concepts found seven relevances, namely: 1) Real } \\
\text { study and essential supporting in freedom learning, broader learning } \\
\text { context 2) Bureaucratic learning, relevant life to support freedom learning. } \\
\text { 3) Learning inquiry based on investigative, complex to support students' } \\
\text { independence in learning. 4) Meaningful, social, and collaborative } \\
\text { learning to support learning resources and good cooperation in learning. } \\
\text { 5) Real-work learning and remember the process, supporting the } \\
\text { contextuality and meaningful learning process. 6) Authentic learning and } \\
\text { interdisciplinary, supporting the breadth and flexibility in developing } \\
\text { knowledge accordance with the world developments. 7) Collaborative } \\
\text { learning teachers, supporting of learning partnerships. }\end{array}$ \\
\hline & $\begin{array}{l}\text { Keywords: Project-Based Lectures, Industrial Revolution 4.0, Meta-Sythesis } \\
\text { Study }\end{array}$ \\
\hline How to cite & $\begin{array}{l}\text { Rokhmawan, T. \& Wulandari, B. (2019).The Relevance of Project-Based Lecture } \\
\text { in Industrial Revolution 4.0: Meta-Synthesis Analaysis. Jurnal Iqra' : Kajian } \\
\text { Ilmu Pendidikan, 4(2). 146-167 } \\
\text { https://doi.org/10.25217/ji.v4i2.515 }\end{array}$ \\
\hline Journal Homepage & http://journal.iaimnumetrolampung.ac.id/index.php/ji/ \\
\hline tis is ant & $\begin{array}{l}\text { icle under the CC BY SA license } \\
\text { https://creativecommons.org/ }\end{array}$ \\
\hline
\end{tabular}

\section{INTRODUCTION}

The expeditious advances on information and communication technology now gave several impacts on education process. Education faces new challenges in the era of information technology and creative industries (Picatoste, Pérez-Ortiz, \& Ruesga-Benito, 2018; Heflin, Shewmaker, \& Nguyen, 2017) Instead of just creating the workers to solve the production needs, education is required to be able to create a generation that has the skills to develop technology and information. The new era requires expertise to do more abstract work (Griffin, McGaw, \& Care, 2012). The primary abilities needed by 
the humans of the 21st century are about these skills: how to think, how to work, tools to work, and ways to live together in the world. Concepts of thinking are conceptualized to include creativity and innovation, critical thinking, problem-solving, learning to learn and metacognition development. and innovation, critical thinking, problem solving, learning to learn and metacognition development (Carlgren, Rauth, \& Elmquist, 2016). The way of work is conceptualized communication, collaboration, and teamwork. Tools for work involve information and information technology literacy. Life in the world involves a changing emphasis on the local and global citizenship, the aspects of life and career development, the last personal and social responsibilities. These are grouped in the KSAVE acronym: knowledge, skills, attitudes, values, and ethics (Griffin, McGaw, \& Care, 2012).

The 21st Century skills framework hypothesizes the relationship between the ability to solve problems, collaboration in problem-solving, and learning through digital networks as a step to support three human abilities in the 21st century (Griffin, McGaw, \& Care, 2012). How to learn and how to teach must be considered into the development of assessment strategies that focus on these skills. In this case, Patrick Griffin then started a project to develop and conceptualize assessment and teaching skills in the 21st century (ATC21s / Assessment and Teaching of 21st Century skills). The International Society for Technology in Education, the main organization on the integration of educational technology in the classroom, has identified 14 conditions needed for schools to utilize technology effectively for lectures (Weinburgh, Collier, \& Rivera, 2003). These critical conditions include: shared vision, empowered leaders, implementation planning, consistent and adequate funding, support policies, equitable access, skilled personnel, assessment and evaluation, engaged communities, ongoing professional learning, technical support, curriculum framework, student-centered learning, and supportive external context (Education, 2007; Education, 2002). ISTE has also developed technology standards (referred to as NETS) for students, teachers, administrators, technology trainers, and computer science teachers that are used to evaluate the skills and knowledge that each group must have about educational technology.

From 1998 to 2017, NETS continued to develop standards for students. In 1998 NETS established standards for students who learn to use technology, 2007 uses technology for learning, until 2016 students who do transformative lectures with technology (Education, 2012). NETS for students (NETS-S) consisted of seven standards in 2016. Standards were realized in the following seven student roles: 1. Empoeded learners: Students use technology to take an active role in choosing, achieving, and showing competence in their lectures, 
informed by science lecture. 2. Digital citizens: Students recognize the rights, responsibilities, and opportunities of life, study, and work in a digital world that is interconnected. They act and model in a safe, legal, and ethical manner. 3. Knowledge Constructor: Students critically curate various resources using digital tools to build knowledge, produce creative artifacts, and create meaningful learning experiences for themselves and others. 4. Innovative Designer: Students use various technologies in the design process to identify and solve problems by creating new, useful, or imaginative solutions. 5 . Computational thinkers: Students develop and use strategies to understand and solve problems in ways that utilize the power of technological methods to develop and test solutions. 6. Creative Communicator: Students communicate clearly and express themselves creatively for various purposes using platforms, tools, styles, formats, and digital media that fit their goals. 7. Global Collaborators: Students use digital tools to broaden their perspectives and enrich their lectures by collaborating with others and working effectively in local and global teams (ISTE, 2016).

NETS for teachers (NETS-T) consisted of seven standards in 2017. The standards are listed in the following seven teacher roles: 1. Teacher as Learner: Educators continue to improve their practice by learning from and with others, exploring proven and promising practices by utilizing technology to enhance student lectures. 2. Teacher as Leader: Educators look for leadership opportunities to support student empowerment and success in order to improve teaching and lectures. 3. Teacher as Citizen: Educators inspire students to contribute positively and participate responsibly in the digital world. 4 . Teacher as a Collaborator: Educators dedicate time to collaborating with colleagues and students to improve practice, find and share resources, ideas, and problem-solving. 5. Teacher as Designer: Educators design authentic activities and environments, driven by students who recognize and accommodate the diversity of students. 6. Teacher as Facilitator: Educators facilitate lectures with technology to support the achievement of ISTE-S Standards (student standards). 7. Teacher as Analyst: Educators understand and use data to encourage their teaching and support students in achieving their learning goals (ISTE, 2017). The beginning background of this idea is to create the students who have the ability to develop their ways of thinking, their ways of working; hence, they can prepare a variety of innovative and modern work tools in accordance with the needs of today. So it utilizes their knowledge to live together in a globalized world through knowledge and skills in the courses presented. "I am optimistic that project-based lectures will be able to support the needs of KSAVE (knowledge, skills, attitudes, values, and ethics) 
for students in utilizing knowledge about folklore. Project-based lectures can also realize 21st-century student and lecturer standards, such as the NETS directive" (ISTE, 2016; ISTE, 2017).

From several previous studies, some explanations were obtained regarding the relationship between project-based lectures and the concepts of educational development in the 21st century and the era of the Industrial Revolution 4.0. Satrianawati (2014) reported about the correlation of projectbased lectures in the challenges of the 21st century with the conclusion: pedagogical paradigms in the application of project-based learning can facilitate science lectures. The students were challenged to learn in the 21st century. But, in her research, Satrianawati did not use specific analysis methods to examine the relevance of project-based lecture concepts and 21st-century developments. Sunarno (2018) discussed conceptual ideas related to science lectures in the industrial revolution era with project-based lectures and Science, Technology, Environment in Modern Society (STEM) approaches. The study was conducted to see the form of student activities and creativity in the STEM approach and project-based lectures, then the results concluded as a form of concepts that lead to lectures in the IR 4.0 era. Other researchers Ellahi, Ali Khan, \& Shah (2019) focused on redisgning curriculum in line with Industry 4.0. It reported curriculum matrix is basically a framework which can be applied as a roadmap for universities to incorporate and adapt Industrial Revolution 4.0 in their curriculum. Unfortunately, the specific points of relevance from the three aspects that are related to relevance (or correlation) have not been formulated

Not many Indonesian publications discuss meta-synthesis studies (or meta-analyzes) of the concepts of lecture development in the context of development in an era. During this time, the meta-synthesis study of lecture development was more associated with efforts to instill educational content (such as values and character) and the development of aspects of child development (cognitive, psychomotor, affective, critical and creative thinking, etc.). Proceeding publication article entitled Innovative Lectures to Embed Character Values in Elementary School Students (Meta-Synthesis Study) by schools (Hidayatullah, Muhardini, \& Haifaturrahmah, 2018). This work contains a meta-synthesis study of concepts and research results related to the development of practices of innovative lectures which are then associated with efforts to instill student character values in elementary schools. The next is a scientific journal publication article with the theme Meta-Analysis of the Effects of lectures with the tactical approach "Teaching Games for Understanding (TGfU)" on the Development of Students' Cognitive Aspects in Physical Education by (Saryono \& Rithaudin, 2011). This work contained a meta- 
synthesis study of TGfU lecture activities (teaching games for understanding) or tactics lectures associated with increased thinking skills, decision-making abilities, and transfers in a game played by students.

From the two previous paragraphs above, regarding previous studies and research, the researchers conclude that meta-synthesis research or meta-analysis of the concept of applying project-based lectures and the development of educational paradigms in the 4.0 era have not been done. In pre-existing writings, project-based lectures are presented as a practice that then concludes the results based on the characteristics of the era's development, then concludes the interrelationships. Whereas in this paper, a comprehensive correlation study will be discussed of the contents of every aspect of the two concepts that are correlated. Also, in previous writings, project-based lectures have been reviewed with meta-synthesis or meta-analysis studies relating to their correlation with character development and thinking ability, while in this paper, the relationship is related to the times.

From the background above, this study uniquely presents the results of a meta-synthesis study of the main points of the educational paradigm in the Industrial Revolution Era 4.0 (Harkins, 2018; Moravec, 2008) and seven projectbased lecture features (Boss \& Krauss, 2007; Krauss \& Boss, 2013; Laur, 2013). From the results of the meta-synthesis study, it was found that the rational linkages between the inter-synthesis networks developed in the educational paradigm of the Industrial Revolution Era 4.0 and seven features of projectbased lectures. A meta-analysis study was carried out by integrating data to obtain new theories and concepts or a deeper level of understanding (Cooper, Hedges, \& Valentine, 2009; Finfgeld-Connett, 2018; Hammond \& Perry, 2002)

The researchers of this paper carry out a meta-synthesis that aims to provide a rational relationship or relevance between the application of projectbased lectures and the development of the educational paradigm in the 4.0 era. So with this aim, the further qualitative-descriptive discussion can be directed to discuss three discussion exposures including 1) Educational Paradigms in the Industrial Revolution Era 4.0, 2) 7 Features of Quality Education in ProjectBased Lectures, and 3) Meta-Synthesis Studies of Concepts Project-Based Lectures in the Industrial Revolution Era 4.0.

\section{RESEARCH METHODOLOGY}

A meta-analysis study was one form of systematic literature review (SLR) research methods. The type of SLR can be in the form of quantitative SLR and qualitative SLR. SLR methods with quantitative approaches are commonly known as a meta-analysis, and SLR methods with qualitative approaches are 
widely recognized as meta-synthesis (Cooper et al., 2009). In this paper, the researchers applied the SLR method with a qualitative, meta-synthesis approach. A qualitative approach in a systematic review is used to synthesize (summarize) research results that are descriptive qualitative. This method of synthesizing (summarizing) the results of qualitative research is called "metasynthesis." By definition, meta-synthesis is a technique for integrating data to obtain new theories and concepts or a more in-depth and more comprehensive level of understanding (Finfgeld-Connett, 2018; Hammond \& Perry, 2002).

A meta-synthesis study was carried out on the main points of the educational paradigm in the Industrial Revolution Era 4.0 and seven projectbased lecture features in five reference books. From the results of the metasynthesis study, the rational linkages of the inter-synthesis networks were obtained to find the linkages of synthesis in the educational paradigm of the Industrial Revolution Era 4.0 and seven features of project-based lectures. The synthesis of the main points of the educational paradigm in the Industrial Revolution Era 4.0 was obtained from Moravec's (2008) exposéd with the heading of the Technological Applications of Leapfrog which was continued in the Harkins (2018) presentation with the Leapfrog Principles And Practices: Core Components of Education 3.0 And 4.0 (Harkins, 2018; Moravec, 2008). While the synthesis of seven project-based lecture features was obtained from the compilation of exposure by Boss \& Krauss (2007) with the book titled Reinventing Project-Based Learning, Your Field Guide to Real-World Projects in the Digital Age, followed by their exposure in 2013 with the headline Thinking through project-based learning: guiding more in-depth inquiry, and supplemented by Laur (2013) with the headline Authentic Learning Experiences, A Real-World Approach to Project-Based Learning. The aspects of the two concepts being compared are analyzed by the cross-sectional method.

\section{RESULT AND DISCUSSION}

The results of the meta-synthesis study can be discussed in three discussion exposures including: 1) Educational Paradigms in the Industrial Revolution Era 4.0, 2) 7 Features of Quality Education in Project-Based Lectures, and 3) Meta-Synthesis Studies of Project-Based Lecture Concepts in the Revolutionary Era Industry 4.0.

\section{Education Paradigm in the Era of the Industrial Revolution 4.0 (IR 4.0)}

The education system is faced with changes in the future of graduates. These changes are: (1) Changing the landscape of job trends where available jobs may be obsolete in the future, but new types of work will emerge to meet 
the demands of the next age, (2) Changing the technological landscape in which an exponential digital era brings technology the unknown; then universities need to consistently anticipate and prepare for changes in new skills and knowledge, (3) Changing students' attitudes and behavior from digital immigrants to digital natives, (4) Changing the demand landscape where we may be faced with unexpected problems in the future. Due to rapid economic and social change, schools/universities must prepare students for jobs that have not yet been created, technologies that have not yet been discovered, and problems that we don't know yet will emerge. The higher education sector is pressured to meet the needs of the digital community which: $20 \%$ are addicted to the internet, $90 \%$ of children and adults play video games, $28 \%$ of people aged 10-34 are involved in reading literature, are bored with traditional lecture models in class, showing differences in the needs and purposes of internet use (Shahroom \& Hussin, 2018).

The presence of IR 4.0 influences the development of human resource qualifications and capabilities. This era empowers students to produce innovation, a follow-up to proof of knowledge. Harkins mapped out taxonomic comparisons of educational contexts in the 1.0 to 4.0 era based on the work of (Harkins, 2018; Moravec, 2008). Figuratively the comparison of educational contexts in the 1.0 to 4.0 era can be seen in detail in the following table

The purpose of the Results and Discussion is to state your findings and make interpretations and/or opinions, explain the implications of your findings, and make suggestions for future research. In the Result section, summarize the collected data and the analysis performed on those data relevant to the issue that is to follow. The result should be clear and concise. It should be written objectively and factually, and without expressing a personal opinion. It includes numbers, tables, and figures (e.g., charts and graphs). Number tables and figures consecutively in accordance with their appearance in the text. 
Table 1. The Comparison of educational context era 1.0 to 4.0

(Harkins, 2018; Moravec, 2008)

\begin{tabular}{|c|c|c|c|c|}
\hline & $\begin{array}{l}\text { "Download" } \\
\text { Education } \\
1.0\end{array}$ & $\begin{array}{l}\text { "Open Access" } \\
\text { Education } \\
2.0\end{array}$ & $\begin{array}{l}\text { Knowledge } \\
\text { Producing } \\
\text { Education } \\
3.0\end{array}$ & $\begin{array}{l}\text { Innovation } \\
\text { Producing } \\
\text { Education } \\
4.0\end{array}$ \\
\hline $\begin{array}{l}\text { The meaning is } \\
\text { conveyed by .... }\end{array}$ & Dictation & $\begin{array}{l}\text { Socially } \\
\text { constructed, with } \\
\text { support for internet } \\
\text { access (limited) }\end{array}$ & $\begin{array}{l}\text { Socially } \\
\text { constructed and } \\
\text { contextually re- } \\
\text { created }\end{array}$ & $\begin{array}{l}\text { Built through the } \\
\text { embodiment of } \\
\text { individuals and } \\
\text { teams that are } \\
\text { selectively driven } \\
\text { in practice, } \\
\text { through focused } \\
\text { innovation }\end{array}$ \\
\hline $\begin{array}{l}\text { Technology is } \\
\text { translated as ... }\end{array}$ & $\begin{array}{l}\text { "Detained at the } \\
\text { door of the class" } \\
\text { or not acceptable } \\
\text { to enter the class } \\
\text { (digital refugees) }\end{array}$ & $\begin{array}{l}\text { Open access } \\
\text { carefully adopted } \\
\text { (digital } \\
\text { immigrants) }\end{array}$ & $\begin{array}{l}\text { "Everywhere", } \\
\text { (digital native in } \\
\text { the digital world) } \\
\text { for the } \\
\text { construction and } \\
\text { transmission of } \\
\text { knowledge } \\
\text { everywhere }\end{array}$ & $\begin{array}{l}\text { Always changing } \\
\text { with direct input } \\
\text { from students who } \\
\text { act as the main } \\
\text { source of } \\
\text { technological } \\
\text { evolution in the } \\
\text { service of } \\
\text { educational } \\
\text { innovation } \\
\text { production }\end{array}$ \\
\hline $\begin{array}{l}\text { The lecture is } \\
\text { completed with } \\
\text {... }\end{array}$ & $\begin{array}{l}\text { From teacher to } \\
\text { student }\end{array}$ & $\begin{array}{l}\text { Teacher to student } \\
\text { and student to } \\
\text { student } \\
\text { (progressivism); } \\
\text { Internet resources } \\
\text { are a normal part } \\
\text { of lecture activities }\end{array}$ & $\begin{array}{l}\text { Teacher to student, } \\
\text { student to student, } \\
\text { student to teacher, } \\
\text { technology-person } \\
\text { (co-construction of } \\
\text { knowledge) }\end{array}$ & $\begin{array}{l}\text { Strengthened by } \\
\text { positive innovation } \\
\text { feedback loops; } \\
\text { everywhere and } \\
\text { creatively in all } \\
\text { phases of life, } \\
\text { study and work. }\end{array}$ \\
\hline $\begin{array}{l}\text { The school is } \\
\text { located in ... }\end{array}$ & $\begin{array}{l}\text { In a building } \\
\text { (brick) }\end{array}$ & $\begin{array}{l}\text { In the building or } \\
\text { online (brick \& } \\
\text { click), but more } \\
\text { and more on the } \\
\text { Web through full } \\
\text { and hybrid (mixed) } \\
\text { internet courses }\end{array}$ & $\begin{array}{l}\text { Everywhere in the } \\
\text { context of } \\
\text { "creative society" } \\
\text { (fully incorporated } \\
\text { into society: cafes, } \\
\text { bowling arenas, } \\
\text { bars, workplaces, } \\
\text { etc.) }\end{array}$ & $\begin{array}{l}\text { In a human body } \\
\text { that has a global } \\
\text { network, } \\
\text { instruments that } \\
\text { continue to } \\
\text { develop } \\
\text { innovatively are } \\
\text { complementary } \\
\text { and replace } \\
\text { classrooms }\end{array}$ \\
\hline $\begin{array}{l}\text { Parents see the } \\
\text { school as ... }\end{array}$ & "Daycare" & $\begin{array}{l}\text { A "daycare center" } \\
\text { with laboratory } \\
\text { excellence, } \\
\text { provided by open } \\
\text { access and a } \\
\text { gradual movement } \\
\text { towards project- } \\
\text { based lectures }\end{array}$ & $\begin{array}{l}\text { A place for } \\
\text { students to create } \\
\text { knowledge, and } \\
\text { for which parents } \\
\text { can provide } \\
\text { domestic, } \\
\text { voluntary, civil, } \\
\text { and fiscal support }\end{array}$ & $\begin{array}{l}\text { The school is seen } \\
\text { as one of the many } \\
\text { places of } \\
\text { innovation for } \\
\text { continuous } \\
\text { innovation by } \\
\text { students, teachers, } \\
\text { parents, etc. }\end{array}$ \\
\hline
\end{tabular}




\begin{tabular}{|c|c|c|c|c|}
\hline & $\begin{array}{l}\text { "Download" } \\
\text { Education } \\
1.0\end{array}$ & $\begin{array}{l}\text { "Open Access" } \\
\text { Education } \\
2.0\end{array}$ & $\begin{array}{l}\text { Knowledge } \\
\text { Producing } \\
\text { Education } \\
3.0\end{array}$ & $\begin{array}{l}\text { Innovation } \\
\text { Producing } \\
\text { Education } \\
4.0\end{array}$ \\
\hline Teacher is... & $\begin{array}{l}\text { Licensed / special } \\
\text { educated } \\
\text { professionals }\end{array}$ & $\begin{array}{l}\text { Licensed } \\
\text { Professionals who } \\
\text { work closely with } \\
\text { students, parents } \\
\text { and others to } \\
\text { (gradually) create a } \\
\text { more engaging } \\
\text { classroom } \\
\text { experience }\end{array}$ & $\begin{array}{l}\text { Everyone, } \\
\text { everywhere, is } \\
\text { supported by } \\
\text { wireless devices } \\
\text { that are designed } \\
\text { to provide raw } \\
\text { material } \\
\text { information for } \\
\text { knowledge } \\
\text { production }\end{array}$ & $\begin{array}{l}\text { Everyone, } \\
\text { everywhere, is a } \\
\text { source of } \\
\text { production } \\
\text { innovation } \\
\text { supported by } \\
\text { "partners" of } \\
\text { intuitive software / } \\
\text { software and } \\
\text { human } \\
\text { collaborators }\end{array}$ \\
\hline $\begin{array}{l}\text { The existence of } \\
\text { hardware } \\
\text { (hardware) and } \\
\text { software } \\
\text { (software) in } \\
\text { schools ... }\end{array}$ & $\begin{array}{l}\text { Purchased at a } \\
\text { large cost and } \\
\text { ignored }\end{array}$ & $\begin{array}{l}\text { open source and } \\
\text { available at a lower } \\
\text { cost, allowing open } \\
\text { access "cheap" and } \\
\text { outside the school } \\
\text { building and } \\
\text { limited access time }\end{array}$ & $\begin{array}{l}\text { Available at low } \\
\text { cost and } \\
\text { intentionally used, } \\
\text { for selective } \\
\text { knowledge } \\
\text { production }\end{array}$ & $\begin{array}{l}\text { Innovated every } \\
\text { day, because } \\
\text { almost all software } \\
\text { is privately owned } \\
\text { and specific, and } \\
\text { without conditions }\end{array}$ \\
\hline $\begin{array}{l}\text { Industry sees } \\
\text { school } \\
\text { graduates as ... }\end{array}$ & $\begin{array}{l}\text { Workers, who } \\
\text { must be trained } \\
\text { because only a } \\
\text { few are in } \\
\text { accordance with / } \\
\text { meet their } \\
\text { expectations }\end{array}$ & $\begin{array}{l}\text { A worker who has } \\
\text { little or no } \\
\text { knowledge of } \\
\text { economic- } \\
\text { production } \\
\text { knowledge }\end{array}$ & $\begin{array}{l}\text { As coworkers and } \\
\text { knowledge- } \\
\text { producing } \\
\text { entrepreneurs who } \\
\text { can support the } \\
\text { development of } \\
\text { focused } \\
\text { knowledge } \\
\text { construction } \\
\end{array}$ & $\begin{array}{l}\text { As partners and } \\
\text { entrepreneurs who } \\
\text { produce } \\
\text { innovations that } \\
\text { can maintain a } \\
\text { focused innovation } \\
\text { construction }\end{array}$ \\
\hline
\end{tabular}

Table 1 presented that IR 4.0 era education deals with innovation and production. In this era, every theoretical definition, terminology, meaning, and guidance is built through individual thinking, work and group discussions, and practices that are developed in an innovative manner; no longer dictated to or just rely on the construction of public thought and internet sources whose sources are unclear. Technology in education always changes according to students' ability to access the latest technology (Ertmer, 2010; Collins \& Halverson, 2018; ISTE, 2017). Students directly support the evolution of technology in developing their creation and innovation, no longer limited to the classroom or dependent on the availability of technology in the class. Organizing teaching is reciprocal between teachers, students, the community, and technology. They, together, build good innovations for living, learning, and doing many things. Teaching, work orders, and sources of knowledge/skills are no longer one-way (teacher to student, student to teacher, student to student, student to the community, or student to technology).

Schools are no longer limited to classrooms, social spaces around students, and the internet or online courses (Ahn \& McEachin, 2017; Leander, 
Phillips, \& Taylor, 2010). The school was within the scope of a global network that continues to develop innovation, complement and replace classroom limitations (Cohen Vogel, Marisa, Stecey A, \& Socol, 2016). It means that students can study wherever they are and reach whatever angle they can achieve individually, socially, and in various internet global networks. The school exists in every human body. Parents see the school as a place for the next generation to continue to develop joint innovations between teachers, students, and parents. Schools are no longer just daycare centers equipped with facilities such as educators, study rooms, laboratories, and children's creative spaces.

The teacher is a facilitator, no longer a certified, licensed, or professional figure designed to provide information about raw materials for the production of knowledge and learning experiences (Becuwe et al., 2016; Farrell, 2016). The teacher is anyone, from anywhere, from any educational background, from any skilled background, from any professional knowledge, and anyone with any experience, capable of being a source of product innovation with intuitive support for " partners "software and human collaborators. Hardware and software in schools are developed every day and can be used by all students because they are used for mutual interest, work, and achievement. The industry sees graduates as partners in producing and innovating, as well as entrepreneurs who are able to build innovation with "capital owners." Graduates are no longer workers who still need to be trained and given special knowledge education in terms of production desired by the industry to increase their production and income.

\section{Seven Features of Education Quality in Project-Based Lectures}

Project-based lectures make each lecture have the potential to produce the latest products in accordance with the development needs of life; make students creative and productive. The development of lecture products can be directed to meet the needs of this era, develop the transformation of traditional products into modern with a touch of digital technology, and provide various forms of scientific results in the way of open access following the need for information disclosure. This condition is under the demands of human competence in the era of the industrial revolution and creative industries in IR 4.0, as I explained above.

Laufenberg, in Krauss \& Boss (2013), stated that project-based lectures/lectures contain high-quality educational features for students: 1) Offering real-world attention and important understanding. Students engage in real-world activities and authentic disciplinary strategies. It is expected to become a common core and other state standards in the new era of education, 
towards an era of authentic lectures and evaluations. ; 2) Be made personal with students choosing the bureaucratic process they learn, often based on dealing with their own lives. Even at the end of the project, students try to create meaningful outside audiences to "prove" their work to others through various methods and technologies. ; 3) The issues in points 1 and 2 above cause them to ask questions, and their investigation requires students to grapple with complexity. At the beginning of project-based lectures, students will face the stage of "determining the project," which requires them to understand situations, problems, focus on the project, get ideas, and make some modifications. It deals with encouraging students to think critically. Sometimes at this stage, students use available technology. Integrated technology, as a tool for discovery, collaboration, and communication, takes the place of learners for which they cannot help teachers achieve important lecture goals in new ways. ; 4) They learn together and from one another, and their lectures are meaningful to people outside of school. Students work collaboratively to solve problems that make them feel uneasy. In working on projects, students need to work closely with others who have different skills, knowledge, ideas, and talents. In this case, students learn to form career connections and learning communities (prototypes of the world of work); 5) Students are influenced by what they learn and tend to remember it. Even in certain situations in working on a project, one needs to justify his idea to be recognized as "real work" done by oneself. Although this is the result of joint work, to be known as contributing individuals, students need to compete in describing ideas and real work. ; 6) Projects form the core of the curriculum - not add-ons at the end of the "real" unit. The design of authentic interdisciplinary learning experiences through project-based lectures can make secure connections with prior knowledge and the world in which students live. These experiences also create relationships in the context of society and careers. ;7) Is developing because teachers collaborate to design and implement projects that cross boundaries of space and time together with students (Boss \& Krauss, 2007; Krauss \& Boss, 2013; Laur, 2013). Figuratively, the seven features of quality education in project-based lectures can be seen in the following chart: 
Chart 1. Seven features of education quality in project-based lectures

\begin{tabular}{|c|c|}
\hline REAL & $\begin{array}{l}\text { - Real-world learning activities and important understanding of } \\
\text { world problems }\end{array}$ \\
\hline $\begin{array}{l}\text { BIROCRATIC \& RELEVANT } \\
\text { WITH LIFE }\end{array}$ & $\begin{array}{l}\text { - The learning process is bureaucratic and is related to the lives } \\
\text { of students themselves }\end{array}$ \\
\hline $\begin{array}{l}\text { INQUIRY, INVESTIGATIVE, } \\
\quad \& \text { COMPLEX }\end{array}$ & $\begin{array}{l}\text { - Inquiry, based on investigation, and dealing with complex } \\
\text { learning contexts }\end{array}$ \\
\hline $\begin{array}{l}\text { MEANINGFUL, SOCIALLY, } \\
\text { \& COLLABORATIVE }\end{array}$ & $\begin{array}{l}\text { - Socially meaningful, collaborative learning and togetherness to } \\
\text { solve problems in learning objects }\end{array}$ \\
\hline $\begin{array}{l}\text { WORKING REALAND } \\
\text { REMEMBERING THE } \\
\text { PROCESS }\end{array}$ & $\begin{array}{l}\text { - Influencing students to work as in real life and making them } \\
\text { remember each lesson }\end{array}$ \\
\hline $\begin{array}{l}\text { AUTHENTIC \& } \\
\text { INTERDISIPLIN }\end{array}$ & $\begin{array}{l}\text { - Make strong connections with prior knowledge and the world } \\
\text { in which students live }\end{array}$ \\
\hline $\begin{array}{c}\text { TEACHER } \\
\text { COLLABORATION \& } \\
\text { STUDENTS }\end{array}$ & $\begin{array}{l}\text { - Is developing because teachers collaborate to design and } \\
\text { implement projects with students }\end{array}$ \\
\hline
\end{tabular}

Meta-Synthesis Study of the Concept of Project-Based Lectures in the IR 4.0 Era

Meta-Synthesis studies of project-based lecture concepts and IR 4.0 era insights are needed to find the links between these two subjects in a conceptual form. It can be done by directly examining detailed sub-concepts in both subjects (project-based lectures and IR 4.0 era insights). The seven project-based lecture features can realize the educational context in the IR 4.0 era. By conducting a Meta-Synthesis study of the concept of project-based lectures and educational contexts in the IR 4.0 era, seven correlation patterns are found: 1) Real and essential lectures, supporting the broader learning context. 2) Lectures that are bureaucratic and relevant to life, support student freedom in learning. 3) the Lectures that are an inquiry, investigative, and complex, support student independence in learning. 4) Lectures that are meaningful, social, and collaborative support the breadth of learning resources and the ability to cooperate in learning. 5) Lectures that work real and remember the process, supporting the contextuality and meaningful learning process. 6) Classes are authentic and interdisciplinary, supporting the breadth and flexibility in developing knowledge in accordance with world developments. 7) Collaborative lectures with teachers and peers, supporting forms of learning 
partnerships. All the links between the project-based lecture features and the taxonomy of the educational context in the IR 4.0 era can be seen in crosslinking in the column list below:

Chart 2. Seven features of education quality in project-based lectures

\begin{tabular}{|c|c|}
\hline $\begin{array}{l}\text { Project-based Lecture } \\
\text { Features }\end{array}$ & $\begin{array}{l}\text { Taxonomy from the educational } \\
\text { context in the era of education } 4.0\end{array}$ \\
\hline $\begin{array}{l}\text { Real learning and understanding of world } \\
\text { problems }\end{array}$ & $\begin{array}{l}\text { Each definition of theory is built through itself by students } \\
\text { individually or in groups, and is innovative }\end{array}$ \\
\hline & $\begin{array}{l}\text { Technology changes according to students' access and } \\
\text { innovation abilities }\end{array}$ \\
\hline $\begin{array}{l}\text { Pembelajarannya birokratis dan terkait } \\
\text { dengan kehidupan siswa }\end{array}$ & $\begin{array}{c}\text { The process of transferring knowledge between teachers, } \\
\text { students, and colleagues is reciprocal for learning and } \\
\text { innovating together }\end{array}$ \\
\hline $\begin{array}{l}\text { Inquiry, investigation, and with complex } \\
\text { learning contexts }\end{array}$ & $\begin{array}{c}\text { The school is within the scope of a global network that } \\
\text { continues to develop innovation, complement and replace } \\
\text { classroom limitations. }\end{array}$ \\
\hline $\begin{array}{l}\text { socially meaningful and collaborative in } \\
\text { solving learning problems }\end{array}$ & $\begin{array}{l}\text { Parents see the school as a place for the next generation to } \\
\text { continue to develop innovation together }\end{array}$ \\
\hline $\begin{array}{c}\text { Students work as in real life and remember } \\
\text { lessons }\end{array}$ & $\begin{array}{l}\text { "Teacher" is anyone (or anything), who is capable of } \\
\text { "partners" and human collaborators. }\end{array}$ \\
\hline & $\begin{array}{l}\text { Hardware and software in schools are developed every day } \\
\text { and used by everyone and interests }\end{array}$ \\
\hline Kolaborasi guru dan siswa & $\begin{array}{l}\text { The industry sees graduates as partners in producing and } \\
\text { innovating, as well as entrepreneurs who are able to build } \\
\text { innovation with "capital owners". }\end{array}$ \\
\hline
\end{tabular}

\section{Real study and essential supporting in freedom learning, broader learning context.}

Real-world lecture activities and essential understanding of world problems can create an educational context that is not limited to classrooms, eliminating space limitations within the scope of global networks or various real spaces around students. In project-based lectures, students are faced with assignments and targets of work that are needed directly to the needs of life in the real world. Students learn in real environmental contexts outside the classroom and overcome a variety of real problems. They found variations in the learning environment directly in the outside class. They are no longer confined to the classroom with variations in the context of learning and contradictions made up. In addition to getting real lectures, students also have 
the opportunity to access a global network between science and the lives of the surrounding social communities.

\section{Bureaucratic learning, relevant life to support freedom learning}

The features of the bureaucratic lecture process related to students' lives can realize the context of students' freedom of thought, in defining philosophical meaning. it is enabling the use of lecture media technology according to the needs and abilities of students' access, and enabling students to position themselves as entrepreneurs in the process of working and producing a product. In project-based lectures, students are allowed to determine their planning and work steps (as easy as not getting out of the rules and ethical constraints in doing assignments) or adjusting their work characteristics to the work steps suggested by the teacher/instructor assignment. Theoretical matters are understood as the knowledge needed to achieve the project objectives, so the meanings of the theories in the book can be developed independently by students. Students are allowed to access all supporting technologies that are able to help them to complete their work as easily as not violating the rules and ethical constraints in doing assignments (such as cheating or using tools to shorten the work process in an instant or cheating way). Students, in this case, put themselves as individuals who have full control over the entire work process and efforts to achieve the expected results; they work as a productive young entrepreneur and determine their success in meeting the demands of work.

\section{Learning Inquiry based on investigative, complex to support students' independence in learning.}

The inquiry feature based on the investigation and the complex context of lectures can realize the ability of students to determine each definition, terminology, meaning, and theoretical guidance through their thinking. Projectbased lectures require students to be an inquiry. It allows students to learn to translate their definitions, meanings, and technical guides in textbooks or other learning resources to help them complete project assignments. In the course of the project lecture, students can only be given a set of guidelines or assignment guidance sheets. Based on the instructions in this assignment sheet, students work to complete the project; only meet with the teacher to get detailed instructions or consultations on problems in completing work. 


\section{Meaningful, social, and collaborative learning to support learning resources and good cooperation in learning}

The social meaning features of collaborative lectures can realize the context of mutual knowledge transfer between each member in the study room, also an opportunity for students to find "teacher figures" from anyone, anywhere, in any situation, at any time. Project-based lectures are not carried out by individuals but in collaboration within a work team. Each individual chooses and has roles, main tasks, and functions to support each other's work. So, in this case, students are possible to share learning experiences, knowledge, and the ability to strengthen the quality of work of his teammates mutually. Every person who can provide benefits, knowledge, and share skills is the "best teacher." One person in the work team has a problem; the other will also have a problem. The purpose of joint work is the responsibility of all members of the work team. The negative side, in this case, might be the presence of members who tend to hamper teamwork. So in this lecture process, positive students' integrity can be tested to be able to work together, overcome social problems in the world of work, and motivate or eliminate "individuals who are the source of problems."

\section{Real-work learning and remember the process, supporting the contextually and meaningful learning process}

Working space features in a real context can create a context that allows students to change and adjust the availability of lecture media technology according to their needs and make the learning space wider than the classroom. Students can work in real contexts and learn to take every concept, process, and learning outcome because they build the entire learning process based on the direction and assignments given by the teacher. This feature allows students to change and adjust the availability of lecture media technology according to their needs and make the learning space wider than the classroom; creative and innovative. In project-based lectures, students develop real learning contexts in real life and learn to change and adapt to the use of technology as needed. Students understand the direction of the project, collect various concepts of knowledge needed, formulate plans, carry out activities, to successfully achieve project objectives, and publish them. The way to help each of these efforts, students, take advantage of a variety of technological aids, that can be achieved to facilitate their work, such as finding scientific concepts and examples of work through browsing access on the internet, compiling plans with computer application aids, carrying out project assignments by utilizing various form of technology in accordance with the product results to be achieved (for example: 
using cameras and amateur video making applications to produce video-based products) to the use of various types of websites (such as social media, online communities, web-blogs, or video-sharing media such as Youtube) for publication purposes.

\section{Authentic learning and interdisciplinary, supporting the breadth and flexibility in developing knowledge accordance with the world developments}

Authentic interdisciplinary learning experience features can create an "unlimited" classroom context, allow students to collaborate with parents and teachers to develop innovations, and develop learning tools according to work needs by utilizing a variety of scientific sources and media. Project-based lectures require students to use a variety of complex and interdisciplinary sciences, as well as a variety of integrated technologies to complete project assignments. To work on a local wisdom documentation video development project, for example, students need knowledge and skills about forms of local wisdom, communication strategies with resource persons, oral data collection strategies and written documents and the use of supporting technology, data transcription techniques to triangulation and summarizing research results using qualitative research data analysis applications such as N-VIVO, research report preparation techniques, research product development techniques in the form of short videos using video maker applications, to online publishing techniques through various types of website facilities available. All of these are complex stages, requiring interdisciplinary knowledge, and integrated technology use skills. For this reason, students' access to knowledge and technology sources is unlimited. They can learn from teachers, parents, seniors, experts in certain fields of technology, to learn self-taught by accessing various tutorial models on the internet.

\section{Collaborative learning teachers, supporting of learning partnerships}

Teacher and student collaboration features can manifest the context of mutual knowledge transfer between the two and enable students to find worklearning partner figures who truly collaborate and support their ideas and abilities. Project-based lectures are a tangible form of scientific collaboration between teachers and students. This is because in working on projects, project ideas are developed jointly by teachers and students. The teacher directs the themes and boundaries while students develop the subjects offered to him to be realized in the form of products according to knowledge, abilities, and technological opportunities that can be achieved. While working on the project, 
greetings preparing work materials, compiling work plans, carrying out the stages of work, to produce products, and reports on the results of project work, students volunteered to get direction and evaluation of the teacher's work. The teacher provides a set of work procedures and a product framework and project reports that must be achieved by students. In essence, students explore all abilities while the teacher directs their work.

The finding of this study was meta-synthesis study of the concept of project-based lectures and the concepts of the development of the IR 4.0 era can realize the educational context in the IR 4.0 era. Meta-Synthesis in two concepts found seven relevances, namely: 1) real study and essential supporting in freedom learning, broader learning context 2) Bureaucratic learning, relevant life to support freedom learning. 3) Learning inquiry based on investigative, complex to support students' independence in learning. 4) Meaningful, social, and collaborative learning to support learning resources and good cooperation in learning. 5) Real-work learning and remember the process, supporting the contextuality and meaningful learning process. 6) Authentic learning and interdisciplinary, supporting the breadth and flexibility in developing knowledge accordance with the world developments. 7) Collaborative learning teachers, supporting of learning partnerships.

The relevance of Project-Based Lectures in the Industrial Revolution Era 4.0 can be found as a form of the results of studies of the work of books that contain a synthesis of the main points of the educational paradigm in the Industrial Revolution Era 4.0 and the synthesis of seven features of projectbased lectures. The synthesized books include: Moravec (2008) with the heading of Technological Applications of Leapfrog which is continued in the presentation Harkins (2018) with the title of the book Leapfrog Principles And Practices: Core Components Of Education 3.0 And 4.0. (3) compilation of the exposure of Boss \& Krauss (2007) with the book title Reinventing Project Based Learning, Your Field Guide to Real-World Projects in the Digital Age, (4) continued with the presentation of Laur (2013) with the book title Thinking through project -based learning: guiding deeper inquiry, and (5) supplemented by Laur's presentation with the book Authentic Learning Experiences, A Real World Approach to Project Based Learning (Laur, 2013).

Differnet from finding other researchers Satrianawati (2014), Sunarno (2018), Ellahi, Ali Khan, \& Shah (2019) did in analyzing the correlation of project-based lectures in the challenges of the 21st century and the IR 4.0 era, the results of this study found more can formulate the existence of 7 (seven) linkages in every aspect of the two comparable concepts, project-based lectures and the development of the Industrial Revolution era 4.0. Moreover, in 
previous studies that tried to analyze the linkages of project-based lectures by meta-analysis or meta-synthesis with the concepts of student affective and cognitive abilities (Hidayatullah, Muhardini, \& Haifaturrahmah, 2018; Saryono \& Rithaudin, 2011), this research was more directed towards its correlation with aspects of the development of the era, IR 4.0.

The results of this study have implications for the opportunities of education practitioners to develop project-based lectures to meet the demands of the quality of education and competence of graduates in the Industrial Revolution 4.0 era. It is hereby recommended for educators to develop and implement project-based lectures in their lecture activities. Every course/lecture can be applied in the form of work projects. The main essence of project-based lectures is the existence of an authentic set of activities in the form: a preliminary assessment of the needs and problems around students, work and collaborative activities, scheduled activities to develop products, to complete product forms, to report and to disseminate information.

\section{CONCLUSION}

From the results of the meta-synthesis study on the synthesis of the main points of the educational paradigm in the Industrial Revolution Era 4.0 and the synthesis of seven project-based lecture features, it was concluded that the relevance of inter-synthesis was seven project-based lecture features can realize the educational context in the IR 4.0 era. From the results of the review of the two concepts obtained seven patterns of relevance, including 1) real study and essential supporting in freedom learning, broader learning context 2) Bureaucratic learning, and relevant life to support freedom learning. 3) Learning inquiry based on investigative, complex to support students' independence in learning. 4) Meaningful, social, and collaborative learning to support learning resources and good cooperation in learning. 5) Real-work learning and remember the process, supporting the contextuality and meaningful learning process. 6) Authentic learning and interdisciplinary, supporting the breadth and flexibility in developing knowledge accordance with the world developments. 7) Collaborative learning teachers, supporting of learning partnerships.

The next suggestion was for the development of assessment and further research. Further studies were needed to explore more deeply the concepts of project-based lectures and the educational context of the Industrial Revolution 4.0 era. Further research was required to develop new forms of project-based lectures with IR 4.0 insights in various fields of science or subjects. 


\section{ACKNOWLEDGEMENT}

This research was made as part of a series of large-funded research, entitled: Documentation of the oral cultural objects of the students of the city of Pasuruan as projects in Folklor lectures. All research was funded by DRPM funding of Minsiter of Research, Technology, and Higher Education, Republic Indonesia. Expression of thanks is addressed to the ministry of technology research and higher education of the Republic Indonesia. For research funding provided under the grant scheme: beginner lecturer research on 2019. Thanks for Mardianingsih, M.Pd for guidance who has given motivation to author to immediately complete this research. Thank you also expressed to all students of the Indonesian language study program at Sekolah Tinggi Keguruan dan Ilmu Pendidikan PGRI Pasuruan of 2019, for their contribution in helping to collect folklore data and in testing research book products.

\section{AUTHOR CONTRIBUTION STATMENT}

Tristan Rokhmawan (TR) is the main author in this paper. Badriyah Wulandari (BW) is the second writer who provides support in being a comparative researcher. TR as the main researcher is the lecturer of Folklor. TR conducts lectures while developing research on project-based Folklor lecturing methods. BW helps researchers to evaluating the implementation of projectbased Folklor lectures, also ensuring that these lectures can be said to be able to develop students' creative and innovative competencies in accordance with the development of the industrial era 4.0

\section{REFERENCES}

Ahn, J., \& McEachin, A. (2017). Student Enrollment Patterns and Achievement in Ohio's Online Charter Schools. Educational Researcher, 46(1), 44-57. https:// doi.org/10.3102/0013189X17692999

Becuwe, H., Tondeur, J., Pareja Roblin, N., Thys, J., \& Castelein, E. (2016). Teacher design teams as a strategy for professional development: the role of the facilitator. Educational Research and Evaluation, 22(3-4), 141-154. https: / / doi.org/10.1080/13803611.2016.1247724

Boss, S., \& Krauss, J. (2007). Reinventing Project Based Learning, Your Field Guide to Real-World Project in the Digital Age. Washington DC: International Society for Technology in Education (ISTE). Google Scholar

Carlgren, L., Rauth, I., \& Elmquist, M. (2016). Framing Design Thinking: The Concept in Idea and Enactment: Creativity and Innovation Management. Creativity and Innovation Management, 25(1), 38-57. https:// doi.org/10.1111/caim.12153 
Cohen Vogel, L., Marisa, R., Stecey A, \& Socol, A. R. (2016). A Model of Continuous Improvement in High Schools: A Process for Research, Innovation Design, Implementation, and Scale. Teachers College Record, 118(13). Google Schoolar

Collins, A., \& Halverson, R. (2018). Rethinking Education in the Age of Technology: The Digital Revolution and Schooling in America. Teachers College Press. Google Scholar

Cooper, H. M., Hedges, L. V., \& Valentine, J. C. (Eds.). (2009). The handbook of research synthesis and meta-analysis (2nd ed). New York: Russell Sage Foundation. Google Scholar

Education, I. S. for T. in. (2002). National Educational Technology Standards for Teachers: Preparing Teachers to Use Technology. ISTE (Interntl Soc Tech Educ. Google Scholar

Education, I. S. for T. in. (2007). National Educational Technology Standards for Students. ISTE (Interntl Soc Tech Educ. Google Scholar

Education, I. S. for T. in. (2012). NETS for Students: A NETS Project. International Society for Technology in Education. Google Schoolar

Ellahi, R. M., Ali Khan, M. U., \& Shah, A. (2019). Redesigning Curriculum in line with Industry 4.0. Procedia Computer Science, 151, 699-708. https://doi.org/10.1016/j.procs.2019.04.093

Ertmer, P. A. (2010). Teacher Technology Change: How Knowledge, Confidence, Beliefs, and Culture Intersect. Journal of Research on Technology in Education, 43(2), 258.

https:/ / doi.org/10.1080/15391523.2010.10782551

Farrell, T. S. (2016). The teacher is a facilitator: Reflecting on ESL teacher beliefs through metaphor analysis. Ranian Journal of Language Teaching Research, 4(1). Google Scholar

Finfgeld-Connett, D. (2018). A guide to qualitative meta-synthesis. New York: Routledge, Taylor \& Francis Group.

Griffin, P. E., McGaw, B., \& Care, E. (Eds.). (2012). Assessment and teaching of 21st century skills, Methods and Approach. Dordrecht; New York: Springer. https:/ / doi.org/10.1007/978-94-017-9395-7

Hammond, N., \& Perry, A. (2002). Systematic Review: The Experience of a PhD Student. Psychology Learning and Teaching, 2(1), 32-35. https:/ / doi.org/10.2304\%2Fplat.2002.2.1.32

Harkins, M. (2018). Leapfrog Principles And Practices : Core Components Of Education 3.0 And 4.0. Tạp Chí Nghiên Cứu dân Tộc, (22). https:// doi.org/10.25073/0866-773X/131 
Heflin, H., Shewmaker, J., \& Nguyen, J. (2017). Impact of mobile technology on student attitudes, engagement, and learning. Computers \& Education, 107, 91-99. https:/ / doi.org/10.1016/j.compedu.2017.01.006

Hidayatullah, R., Muhardini, S., \& Haifaturrahmah, H. (2018). Pembelajaran Inovatif untuk Menanamkan Nilai-Nilai Karakter pada Siswa Sekolah Dasar (Studi Meta-Sintesis). 486-494. Retrieved from Google Scholar

ISTE. (2016). ISTE Standards for Students - A Practical Guide for Learning With Technology. International Society for Technology in Education (ISTE).

ISTE. (2017). ISTE Standards for Educators - A Guide for Teachers and Other Profesionals. International Society for Technology in Education (ISTE). Google Scholar

Krauss, J., \& Boss, S. (2013). Thinking through project-based learning: guiding deeper inquiry. Thousand Oaks, Calif: Corwin. Google Scholar

Laur, D. (2013). Authentic Learning Experiences, A Real World Approach to Project Based Learning. NewYork: Routledge. Google Scholar

Leander, K. M., Phillips, N. C., \& Taylor, K. H. (2010). The Changing Social Spaces of Learning: Mapping New Mobilities. Review of Research in Education, 34(1), 329-394. https:/ / doi.org/10.3102/0091732X09358129

Moravec, J. W. (2008). Technological Applications of Leapfrog. Futures Research Quarterly, 24(1), 59-67. Google Scholar

Picatoste, J., Pérez-Ortiz, L., \& Ruesga-Benito, S. M. (2018). A new educational pattern in response to new technologies and sustainable development. Enlightening ICT skills for youth employability in the European Union. Telematics and Informatics, 35(4), 1031-1038. https:/ / doi.org/10.1016/j.tele.2017.09.014

Saryono, \& Rithaudin, A. (2011). Meta Analisis Pengaruh Pembelajaran Pendekatan Taktik (TGfU) terhadap Pengembangan Aspek Kognitif Siswa dalam Pendidikan Jasmani. Jurnal Pendidikan Jasmani Indonesia, 8(2), 144-151. (Jurusan Pendidikan Olahraga Fakultas Ilmu Keolahragaan Universitas Negeri Yogyakarta). Google Sholar

Satrianawati. (2014, December). Project Based Learning dalam Tantangan Pembelajaran Sains Abad XXI. Vol. 2 No. 1, 12. Google Scholar

Shahroom, A. A., \& Hussin, N. (2018). Industrial Revolution 4.0 and Education. International Journal of Academic Research in Business and Social Sciences, 8(9), Pages 314-319. https://doi.org/10.6007/IJARBSS/v8i9/4593

Sunarno, W. (2018). Pembelajaran IPA di Era Revolusi Industri 4.0. Peran Pendidik dan Ilmuwan Sains dalam Menyongsong Revolusi Industri 4.0, IV, 8. Retrieved from Google Schoolar 
Weinburgh, M., Collier, S., \& Rivera, M. (2003). Preparing elementary teachers: Infusing technology as recommended by the International Society for Technology in Education's National Educational Technology Standards for Teachers (NETS.T). Teach Trends, 47(4). Google Scholar

\section{Copyright Holder :}

(C) Rokhmawan, T. \& Wulandari, B. (2019).

First Publication Right :

(C) Jurnal Iqra' : Kajian Ilmu Pendidikan

This article is under:

(ㅇ) (1) (2) 